\title{
Yield and yield-reduction in recent drought years in southern Tigray, northern Ethiopia: Implications on food security
}

\section{Emmanuel Eze ( $\nabla$ eze.emma@unn.edu.ng)}

Geographical and Environmental Education Unit, Department of Social Science Education, University of Nigeria https://orcid.org/0000-0003-2007-2696

\section{Atkilt Girma}

Mekelle University, Mekelle, Ethiopia

\section{Amanuel Zenebe}

Mekelle University, Mekelle, Ethiopia https://orcid.org/0000-0001-6571-9065

\section{Chukwuebuka Christopher Okolo}

Department of Land Resource Management and Environmental Protection, Mekelle University https://orcid.org/0000-0001-

7284-2512

\section{Emnet Negash}

Institute of Climate and Society, Mekelle University https://orcid.org/0000-0001-8553-6602

\section{Research}

Keywords: climate change, crop yield, drought, food security, yield loss

Posted Date: October 23rd, 2020

DOI: https://doi.org/10.21203/rs.3.rs-31805/v3

License: @ (1) This work is licensed under a Creative Commons Attribution 4.0 International License. Read Full License

Version of Record: A version of this preprint was published at Scientific Reports on April 15th, 2022. See the published version at https://doi.org/10.1038/s41598-022-09862-x. 


\section{Abstract}

The consequences of prolonged precipitation-deficient periods are primarily substantial water deficit, with the spatial characteristics of drylands and various socioeconomic factors worsening its impacts and deepening poverty among agrarian communities, with attendant food security implications. This study utilizes a combination of climate, remote sensing and field survey data. These data were used to obtain a first-hand information on the impacts of recent (2015 and 2017) droughts on crop yield in southern Tigray, northern Ethiopia. Annual and seasonal rainfall, annual and seasonal NDVI and Dev-NDVI, and monthly SPI-1, SPI-3 and SPI-12 (for June to October) were considered as likely factors that could relate with yield and yield loss in the area. Correlation and multiple linear stepwise regression statistical techniques were used to determine drought-yield relationships, and identify more accurate predictors of yield and yield losses in each of the drought years. The area witnessed a more widespread precipitation deficit in 2015 than in 2017, where the lowland area recorded entire crop losses. Also, droughts manifested spatiotemporal variations and impacts across the 3 different agroecologies - primarily reduction in vegetation amounts, coinciding with the planting and maturing stages of crops. Crop failures therefore translated to food shortages and reduced income of smallholders, which denotes food insecurity in the time of droughts. Seasonal rainfall and June Dev-NDVI predicted $66.9 \%$ of 2015 yield loss, while NDVI predicted 2017 sorghum yield by $96 \%$. Spate irrigation should be further popularized in the low-lying areas of Raya Azebo to augment for future deficiencies in the kiremt rainfall.

\section{Introduction}

Global climate change has resulted in increasing occurrence of extreme weather and climatic events such as floods and droughts. According to Eze et al. (2020), Negash et al. $(2019,2020)$, outputs of rain-fed agriculture are at risk of influence by drought events. Droughts occur when a shortage of precipitation is received in a given season, or when there is a departure from a known average. Bayissa et al., (2018) designate an abnormally prolonged dry condition as drought, whereas in the view of Wilhite (2000), the timing and the effectiveness of precipitation could be linked to drought, hence making each drought event unique in impacts and characteristics. The consequences of prolonged precipitation-deficient periods are primarily substantial water deficit. Water shortages are exacerbated by the spatial characteristics of a drylands, especially in arid and semi-arid environments. Additional disadvantages such as a largely rural population with very little education, totally dependent on agriculture for living and livelihood, and a limited capacity to withstand droughts could further extend impacts of droughts.

Ethiopia is a Sub-Saharan country in East Africa largely susceptible to droughts. Although, some parts are more vulnerable than the other, the intensity and frequency of droughts is increasing. While Viste et al. (2013) indicate that Ethiopia is largely droughtprone, the account of Mera (2018), shows that the northern parts of Ethiopia experience droughts every 3-5 years, with a recent successive occurrence in 2015-2017. Such circumstances have been opined by Qu et al. (2019) to worsen food security issues. In describing the impacts of the most recent droughts, the Federal Democratic Republic of Ethiopia [FDRE] (2017) reports that in 2015, drought in Ethiopia was linked with the global El Niño weather phenomenon, thus resulting in food insecurity for 10.2 million people, while Mera (2018) has it that the 2017 short season (March-April) rainfall was virtually a failure. Such impacts are capable of being magnified, as Gray and Mueller (2012) connect deep rural poverty with the amplification of drought effects in Sub-Saharan Africa.

Economically, droughts could deepen poverty levels especially among the largely agrarian populace of developing countries. Again, the FDRE (2017) estimates the Gross Domestic Product (GDP) losses due to climate variability to be around $1 \%$ to $4 \%$. Tigray region in the northern part of Ethiopia has been identified as one the most drought-vulnerable crop-production regions. The study of Gebrehiwot et al. (2016), classifies Tigray as one the 'most severely affected (regions) during well-known famines', where a slight rainfall-deficiency can result in crop failure, with a direct impact on food security of households. Crop failure has been attributed to the paltry amount of water stored in the soil during a prolonged dry spell (Marteau et al., 2011; Mugalavai et al., 2008). Therefore, protracted precipitation deficit to the extent of the depletion of soil moisture becomes critical for crops, especially at early stages of development and maturity, with profound impacts on eventual yield in any given season. 
Thus, in order to detect and estimate droughts and their impacts, some indicators and indexes have been developed over the years. The characteristics of a drought event - onset, intensity, spatial coverage and duration, can be expressed using a drought index. In the opinion of Sivakumar (2011), parameters such as rainfall, runoff, temperature and evapotranspiration should be included in a drought index to enhance its usefulness in describing a drought event. Drought indexes have been generally grouped into meteorological, soil moisture, hydrological, remote sensing and composite/modeled indicators, to correspond with their design and scope of operations. This study is delimited to metrological and remote sensing indicators.

The commonly used meteorological drought indicators include Standardized Precipitation Index (SPI) and Standardized Precipitation Evapotranspiration Index (SPEI). The SPI is recommended by the World Meteorological Organization WMO (2012) to be used by all National Meteorological and Hydrological Services around the world to characterize meteorological droughts. Designed by McKee, Doesken, and Kieist (1993) to quantify the magnitude of dry and wet conditions in a desired location, the SPI is effective in drought detection in multiple time-scales, generally between 1 and 48 months. The WMO and GWP (2016) posit that SPI values for 3 months (SPI-3) or less, might be useful for basic drought monitoring; while values for 6 months (SPI6) or less, are fit for monitoring agricultural impacts; and values for 12 months (SPI-12) or longer, are ideal for hydrological impacts. With precipitation being the only input, SPI is deficient when accounting for the temperature component of droughts, as water balance/use are not accounted for. However, SPI is still adopted in this study in spite of the obvious deficiency due to the unavailability of temperature data.

A lot of satellite-based indicators have been developed, with ability to accurately detect droughts over large spatiotemporal resolutions. The Normalized Difference Vegetation Index (NDVI) is a popular drought-monitoring index developed by Kogan (1995), for determination of droughts by the measurement of vegetation vigor and cover in an index ranging from -1 to +1 . However, the NDVI itself needs to be computed vis-à-vis anomalies in order to clearly indicate the presence of drought and its severity. The Dev-NDVI, which is the deviation of NDVI from its long-term mean will easily indicate the magnitude of wetness or dryness of an area. Hence, a negative Dev-NDVI is an indicator of below-normal vegetation condition/health, thus suggesting a drought situation. The magnitude of a drought spell is defined by the degree of negative departure from the long-term mean NDVI (Kidwell, 1990; Thenkabail et al., 2004). The NDVI and Dev-NDVI are therefore used in this study to obtain a clear perception of agricultural droughts.

Many drought studies have focused on assessment of both meteorological and agricultural droughts in Ethiopia. While Gebrehiwot et al. (2016) undertook a determination of spatiotemporal seasonal agricultural drought in Ethiopia during the 1998 to 2013 cropping seasons; Suryabhagavan (2017) characterized meteorological droughts and climate variability in Ethiopia over three decades (1983 to 2012). The study of Qu et al. (2019) on impacts of drought, includes other countries aside Ethiopia and covering the Horn of Africa, while that of Gidey et al. (2018) characterized the occurrence of drought in northern Ethiopia for 15 years (2001 to 2015). Only the study of Warner and Mann (2018) adopted an integrative approach of the use of satellite (GIS) data with conventional agricultural survey data to assess drought impacts, hence the essence of this study for the area. This study rather than characterize or report drought impacts by use of indicators, or other secondary data, further utilizes the climate and remote sensing data, with field survey data from farmers to obtain first-hand information on the impacts of droughts on crop yield, and then determines climatic and vegetation drought indicators which are able to closely predict farmers' yield in the recent drought events (of 2015 and 2017). Therefore, the objective and important contribution of this study to scientific knowledge of drought is to provide an insight into what drought indicators (meteorological and vegetation/remote sensing) closely relate to and predicts farmers' crop yield, using a small geographical area, with opportunities of further discourse.

\section{Materials And Methods}

Page $3 / 22$ 


\section{The study area}

This study was implemented in two purposively selected woredas (districts) in the southern Tigray region, northern Ethiopia. Tigray has been previously established as one of the most drought-vulnerable regions in

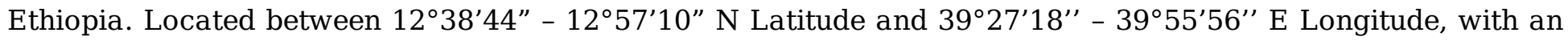
altitude ranging from 1109 to $3760 \mathrm{~m}$ above sea level (m.a.s.l.). The study area includes one district of mid and highland agroecology (Endamehoni) and another woreda (Raya Azebo) of lowland agroecology. Nine (9) tabias/kabeles (villages) are included in the portion selected for this study (Figure 1).

\section{Data sources and analysis methods}

\section{Meteorological data}

The Climate Hazards group InfraRed Precipitation with Stations (CHIRPS) grid precipitation dataset from 2015 to 2018, obtained from (ftp://ftp.chg.ucsb.edu/pub/org/chg/products/CHIRPS-2.0/) was used for this study. The CHIRPS is the combination of a "high-resolution climatology, time-varying cold cloud duration precipitation estimates, and in situ precipitation estimates", with high research quality and very low errors (Funk et al., 2014; Shukla et al., 2017). The high reliability, spatial spread and accuracy of the CHIRPS over the point-based data makes it preferred for this study. Also, Bayissa (2018) and Gebrechorkos et al. (2018) have earlier confirmed the accuracy of the CHIRPS data for use in studies on Ethiopia. The rainfall variables used in the study include the annual and main (kiremt) season (JJAS) rainfall.

\section{Satellite images data}

The Moderate Resolution Imaging Spectroradiometer (MODIS) MOD13Q1 composite images with 250-m resolution data obtained from the NASA Land Processes Distributed Active Archive Center (LP DAAC), USGS/Earth Resources Observation and Science (EROS) Center (https://pdaac.usgs.gov/data _access/data_pool), was used for this study. In the opinion of (Wu et al., 2015) MODIS data products are accurate and appropriate for drought monitoring. Following download, the images were re-projected and resampled from a sinusoidal to geographic projection (WGS84); and then NDVI values were extracted from the re-projected (*.tif) images using $\mathrm{R}$ scripts. To obtain the conventional NDVI values ranging from -1 to +1 , the extracted values were rescaled with the factor 0.0001 . The NDVI variables used in this study includes the Annual NDVI, from which the Dev-NDVI of the main cropping (kiremt) season, and the monthly Dev-NDVI of June to October.

\section{Farmers' yield (survey) data}

A one-time direct interview of 34 farmers was used for this study. These 34 farm owners (sorghum = 16; barley = 18) are randomly selected, and are those with high yield recall from memory. While more farmers were interviewed as they are always found in groups, only those who met our criteria of crop type and recent crop yield memory, were included the study, with their farmlands measured with the use of IPAQ, for appropriate relation of the yield to specific farmlands. Two cereal crops - barley and sorghum were selected in the highland and lowland respectively, due to their widespread importance as dominant crops and staple foods in the area, and also to improve the accuracy of yield recall from farmers' memory. 


\section{Data analyses}

\section{Data pre-processing procedures}

The analysis of historical meteorological droughts was done using the Standardized Precipitation Index (SPI) in $\mathrm{R}$ software version 3.4 with the aid of suitable scripts and packages. The SPI was calculated on three timescales: 1-, 3- and 12-month (SPI-1, SPI-3, and SPI-12). To obtain agricultural droughts Dev-NDVI was calculated using the equation (1).

DevNDVI $=N D V I_{i}-N D V I_{\text {mean-m }}$

Where the $N D V I_{i}$ is the NDVI value for month ' $i$ '; $N D V I_{\text {mean-m }}$ is the long-term mean NDVI for the same month $\mathrm{m}$ over the spatiotemporal period.

Three operations were implemented to get three variables of yield data for the analyses.

1. Using the raw yield data obtained from farmers, conversion to yield per hectare was done by dividing the actual (raw) yield value by the area of land and multiplying the result by 10,000 (which is the area of a hectare). Hence the formula:

$$
\text { YpHa }=\frac{\text { Actual Yrela }}{\overline{\text { Area }\left(m^{2}\right)}} \times 10,000
$$

Where:

Actual yield = raw yield values obtained from farmer;

$\operatorname{Area}\left(\mathrm{m}^{2}\right)=$ total area of farmer's plot in $\mathrm{m}^{2}$;

$10,000=$ total meter squares $\left(\mathrm{m}^{2}\right)$ in a hectare

1. The yield per hectare (YpHa) data was used to compute a Standardized variable of crop yield (SCY) for each of the sampled Tabias within the study area, using equation (3).

- The SCY was then be used to obtain the crop yield loss ratio (YLR) of the area, using equation (4). The formulae applied to obtain the SCY and the YLR has been used in a recent study of Elhag \& Zhang (2018) to monitor the impact of drought on crop yield elsewhere.

$$
\begin{aligned}
& S C Y=\frac{Y j-Y}{\sigma} \\
& Y L R=\frac{\bar{Y}-Y j}{\bar{Y}} \times 100 \%
\end{aligned}
$$

Where:

$Y j$ is the crop yield in $j$ Year of a Tabia;

$\bar{Y}$ is the average, and $\sigma$ is the standard deviation of crop yield during the period under review. 


\section{Correlating yield, climatic and drought-indicator variables}

To obtain the relationship between drought and crop yield in the study area, YpHa, SCY and YLR for 2015 and 2017 were correlated with annual rainfall; kiremt rainfall; annual NDVI; annual Dev-NDVI; kiremt Dev-NDVI; monthly Dev-NDVI (for June to October); and monthly SPI-1, SPI-3 and SPI-12 (for June to October). The use of all these variables in measuring the relationship is to determine which factor is most related to the declared farmers' yield and losses for the years under review.

The analysis of the relationship between variables listed above with YpHa, SCY and YLR was done in three batches. Firstly, the relationships across the entire study area was assessed. Next, a split woreda-based analysis was conducted to ascertain the relationships based on the two different woredas (Endamehoni and Raya Azebo) selected for the study. The purpose of the split-site analysis is to account for inherent variations expected in rainfall patterns, crop yield and crop loss in the two agroecologically dissimilar districts (woredas).

The non-parametric (Spearman's) correlation analysis was implemented, as this would not demand bivariate normality of the dataset. Some previous studies such as Clarke, (2017); Gunst et al., (2014); Marshall, Funk, and Michaelsen (2012); Shukla, Mcnally, Husak, and Funk (2014) all adopted the Spearman's correlation for their analyses. Interpretation of the strength of association among variables as reflected by the resultant correlation coefficients adopted in this study were obtained from the groupings of Cohen, Cohen, West, \& Aiken (2003) as shown below (Table 1).

Table 1: Correlation coefficients and their interpretation

\begin{tabular}{|c|c|c|c|}
\hline \multicolumn{2}{|c|}{ Positive relationship } & \multicolumn{2}{|c|}{ Negative relationship } \\
\hline Coefficients & Strength & Coefficients & Strength \\
\hline 0.10 to 0.29 & Weak/small & -0.10 to -0.29 & Weak/small \\
\hline 0.30 to 0.49 & Moderate/medium & -0.30 to -0.49 & Moderate/medium \\
\hline 0.50 to 1.00 & Strong/large & -0.50 to -1.00 & Strong/large \\
\hline
\end{tabular}

Source: Adapted from Cohen et al. (2003)

\section{Regressing yield, climatic and drought-indicator variables}

Multiple linear stepwise regression was implemented in SPSS to obtain the most significant and relevant predictors for both crop yield and yield loss in the drought years of 2015 and 2017. The stepwise regression is an approach to selecting a subset of effects for a regression model and has been widely used in literature, with several authors preferring its application where little theory to guide the selection of terms for a model exists; or where there is the focus on predictors which interactively seem to provide a good fit; and where the performance of a model is to be improved by reducing the variance from unnecessary terms (Bachmair et al., 2018; Blauhut et al., 2016; Jones et al., 2011; Yahaya and Timothy, 2015; Zhu et al., 2018). The stepwise regression also exempts variables of high multicollinearity (variance inflation factor - VIF) in the selection of the most relevant predictors, hence its adoption in this study. The step-wise multiple regression was therefore conducted using the threshold of probability of the predictor to enter as $<=0.050$ and the probability of the predictor to be removed as $>=0.100$. 


\section{Results}

\section{5 drought and crop yield: relationship and climatic/vegetative predictors}

The results are presented in three subsections to represent the lowland case study (Raya Azebo), the highland case study (Endamehoni), and the entire study area. These sections correspond to the three-batch analyses implemented to unravel the relationship of drought with crop yield, and arriving at key drought indicators that more accurately predicted the crop yield in the event of drought. Figure 2 contains key spatial variables used to obtain the results.

\section{Raya Azebo (lowland)}

For the sampled area in Raya Azebo, only annual rainfall, values show a strong positive significant correlation with SCY and YpHa, while June and October SPI-1 indicate a strong negative association with SCY and YpHa (Supplementary Table S2). This implies that higher annual rainfall translates to higher crop yield while higher meteorological drought in June and September led to lower crop yield. Kiremt season rainfall also had a strong positive significant relationship with YpHa. Other notable variables indicating a moderate positive relationship with YpHa and SCY are annual Dev-NDVI, kiremt Dev-NDVI; while a moderate negative relationship exists between July and August SPI-1, June and July SPI-1; June and October SPI-3 (Supplementary Table S2). Annual rainfall and kiremt season rainfall had a strong negative relationship with YLR. Hence, the lower the (annual and kiremt) rainfall, the higher the yield loss. On the other hand, annual Dev-NDVI, June and October SPI-1 are strongly positively and significantly associated with YLR. Hence, higher deviation from NDVI and higher meteorological drought reflected in higher crop losses. Kiremt Dev-NDVI, June Dev-NDVI, July SPI-1, June and October SPI-3, and June SPI-12 were moderately positively correlated with YLR

Annual rainfall and July SPI-3 are the most significant predictors of SCY in Raya Azebo. The two-step regression (Supplementary Table S7) results show that annual rainfall alone explains 38\% of the variation in the standardized crop yield while and the combination of both predictors - annual rainfall and July SPI-3 for the year explain 56.3\% of the variation in SCY for Raya Azebo (Table 2). Similar to the SCY, the YpHa is significantly predicted by annual rainfall and July SPI-3 with the coefficient of determination $\left(r^{2}\right)$ indicating that $35.7 \%$ of the variations in the yield per hectare obtained in the study area is attributed to annual rainfall alone, while the combination of annual rainfall and July SPI-3 explains 53.3\% of the variations (Table 2). For the 2015 season, about $75 \%$ of farmers sampled in Raya Azebo had zero yield and 100\% of crop losses. The stepwise regression for YLR was unsuccessful due to the multiple zero figures.

\section{Endamehoni (highland)}

There are slightly different results obtained in the analyses of data in this area. There is a strong negative significant relationship between kiremt Dev-NDVI, June Dev-NDVI, July and September SPI-1 and SPI-3; and July September and October SPI-12, all with YpHa (Supplementary Table S3). The SCY had a strong negative significant relationship with kiremt Dev-NDVI, September SPI-1; July and September SPI-3; and July, September and October SPI-12. Additionally, it is worthy of mention that the correlation between kiremt season rainfall, August SPI-1, June, August and October SPI-3, and August SPI-12 with YpHa and SCY were moderately negative, though not significant. Therefore, higher wetness led to lower yield in this woreda. The crop yield loss was strongly and positively significantly related with Annual Dev-NDVI, June Dev-NDVI, August and September SPI-1; June to October SPI-3, and August to October SPI-12. Furthermore, kiremt season rainfall, July SPI-1 and 
July SPI-12 showed a moderate positive relationship with the YLR but not significant. Higher rainfall reflected in higher yield loss in this area and higher Dev-NDVI did not imply higher yield as crop losses were recorded due to excessive rainfall, as confirmed by data obtained during farmers' survey (Supplementary Table S3).

October SPI-12 is the most significant predictor of SCY in Endamehoni for 2015. The coefficient of determination $\left(r^{2}\right)$ show that October SPI-12 explain $43.7 \%$ of the variation in standardized crop yield in the area for the year under review (Table 2). For the YpHa, October SPI-12 and August Dev-NDVI are the key predictors, with $42.2 \%$ of the variations in the yield per hectare obtained in the study area attributed to October SPI-12 alone, while the combination of August Dev-NDVI with October SPI-12 explains 56.9\% of the variations in yield per hectare. A two-step regression (Supplementary Table S7) indicates September SPI-12 and October Dev-NDVI as the key predictors of yield loss. The coefficient of determination $\left(r^{2}\right)$ show that September SPI-12 alone explains $38.4 \%$ of the variation in yield loss ratio; while the combination of September SPI-12 and October Dev-NDVI explain 62.4\% (Table 2).

\section{Entire study area}

From the results obtained from the entire area analysis, there is a strong positive significant relationship between Annual Rainfall and Kiremt Rainfall with farmers' YpHa and SCY (Supplementary Table S1). This implies that higher rainfall led to higher crop yield. Conversely, there is a strong negative significant relationship between annual rainfall, kiremt rainfall and farmers' YLR. In addition, the annual NDVI shows a strong positive significant relationship between YpHa and SCY while annual Dev-NDVI shows a moderate/medium positive significant relationship between the same variables. This implies that deviation of vegetation index from the long-term average does not always translate to yield reduction. Farmers' YLR show a moderate negative significant relationship with Annual NDVI and a weak negative relationship with Annual Dev-NDVI (Supplementary Table S1).

Furthermore, the monthly Dev-NDVI indicate various relationships with farmers' YpHa, SCY and YLR. The SPI at the 1, 3, and 12-month scales show different levels of relationship for different months with the YpHa, SCY and YLR. At the 1-month scale of SPI there is a strong negative significant relationship between YpHa, SCY and SPI-1 values for the months of June and October, with August showing a nearly strong negative significant association (Supplementary Table S1). This implies that higher SPI-1 drought during the planting and maturing stages impacted crops' performance and resulted in yield reduction. A strong positive significant relationship exists between YLR and SPI-1 for the months of June, August and October meaning that higher droughts in these months, which are crucial growing and maturing phases of crops studied, translates to higher yield losses. The 3-month scale of SPI shows a strong positive significant relationship with YpHa and SCY in the month of September and a strong negative significant relationship with YLR. For the 12-month scale of SPI, a strong positive significant relationship exists between YpHa and SCY in the months of July, September and October (Supplementary Table S1). While the YLR has a strong negative significant relationship with July and September SPI-12, it has a medium negative significant relationship with October SPI-12 values (Supplementary Table S1). Hence, higher SPI-12 drought in July and September led to higher crop losses, whereas October drought had no major impact on crop losses. 
Kiremt season rainfall, June Dev-NDVI and annual NDVI are the key predictors for SCY in the entire study area. From the three-step regression, kiremt rainfall alone explains 39.8\% of the variation in the standardized crop yield; Kiremt rainfall and June Dev-NDVI explain 50.4\%; and the combination of all three predictors- kiremt rainfall, June Dev-NDVI and the annual NDVI for the year explain 57.5\% of the variation in crop yield in the study area. The key predictors for YLR are kiremt rainfall and June Dev-NDVI. The two-step regression shows that kiremt rainfall alone explains $51.3 \%$ of the variation in yield loss ration; while the combination of kiremt rainfall and June Dev-NDVI explain 66.9\% (Table 2). Some additional variables that are excluded from the stepwise threshold, though with significant predictive possibilities but high multicollinearity, include the September SPI-3 ( $\mathrm{p}=.047)$ and October SPI-12 ( $\mathrm{p}=.046)$. From a one-step regression analysis (Supplementary Table S7), annual rainfall is the most significant predictor of YpHa. The coefficient of determination $\left(r^{2}\right)$ obtained shows that $40.3 \%$ of the variations in the yield per hectare obtained in the entire study area is attributed to annual Rainfall.

Table 2: Predictors of YpHa, SCY and YLR in the 2015 drought year in the study area

\begin{tabular}{|c|c|c|c|c|c|c|}
\hline Location & Variable & Highest regression step & Predictors & $\mathbf{R}$ & $\mathbf{R}^{2}$ & Sig. \\
\hline \multirow[t]{4}{*}{ Raya Azebo } & YpHa & 2 & Annual_RFE, July15_SPI3 & .730 & .533 & $.003^{* *}$ \\
\hline & SCY & 2 & Annual RFE Iulv15 SPI3 & 750 & 563 & $\begin{array}{l}.045^{*} \\
002 * *\end{array}$ \\
\hline & & & & & & $037 *$ \\
\hline & YLR & Nil & & & & \\
\hline \multirow[t]{5}{*}{ Endamehoni } & YpHa & $\frac{1+1}{2}$ & oct15_SPI12, Aug15_DNDVI & .754 & .569 & $.001^{* * *}$ \\
\hline & & & & & & $.039 *$ \\
\hline & SCY & 1 & oct15_SPI12 & .661 & .437 & $.003 *$ \\
\hline & YLR & 2 & sep15_SPI12, oct15_DNDVI & .790 & .624 & $.001 * * *$ \\
\hline & & & & & & $.007 * *$ \\
\hline \multirow[t]{6}{*}{ Entire area } & YpHa & 1 & Annual RFE & .635 & .403 & $.000^{* * *}$ \\
\hline & SCY & 3 & KRFE2015, jun15_DNDVI, ND15 & .758 & .575 & $.004^{* *}$ \\
\hline & & & & & & $.002^{* *}$ \\
\hline & & & & & & $.003 * *$ \\
\hline & YLR & 2 & KRFE2015, jun15_DNDVI & .818 & .669 & $.000 * * *$ \\
\hline & & & & & & $.001 * * *$ \\
\hline
\end{tabular}

*** Regression Predictor is significant at the above 0.001 level

** Regression Predictor is significant at the 0.01 level

* Regression Predictor is significant at the 0.05 level

\section{7 drought and crop yield: relationship and climatic/vegetative predictors}

The pattern observable (Figure 3) is inconsistent with the 2015 drought year (Figure 2) as there was no location that recorded 100\% crop loss. Also, areas that had higher crop losses in the previous drought of 2015 had better and improved yield in this season. As above, the results are presented in three subsections to represent the lowland case study (Raya Azebo), the highland case study (Endamehoni), and the entire study area. These sections also correspond to the three-batch analyses implemented to unravel the relationship of 
drought with crop yield, and arriving at key drought indicators that more accurately predicted the crop yield in the drought events.

\section{Raya Azebo (lowland)}

There is a strong positive significant relationship between annual NDVI with YpHa and SCY. A positive moderate not-significant relationship also exists between kiremt Dev-NDVI, YpHa and SCY (Supplementary Table S5). June to September Dev-NDVI values show a moderate negative not-significant relationship with YpHa and SCY. Crop loss relates moderately with kiremt season rainfall, June and July Dev-NDVI, August SPI-1; July to September SPI-12 values. All these are not significant in their relationship. However, June SPI-3 has a strong negative significant relationship with YLR while October SPI-12 has a strong positive relationship with YLR, which is also significant (Supplementary Table S5).

The results of a seven-step multiple regression (Supplementary Table S8) indicate that annual NDVI for 2017, and June to October Dev-NDVI values are key predictors of SCY. The combination of annual NDVI, June DevNDVI, August Dev-NDVI, July Dev-NDVI and October Dev-NDVI explains 96\% of the variation of SCY in Raya Azebo for this farming season. Similarly, a seven-step regression presents the annual NDVI and Dev-NDVI, June SPI-12, June, August and September Dev-NDVI as the most significant predictors of YpHa with 96.6\% explanation of the variation in yield per hectare obtained in Raya Azebo (Table 3). The key predictor of crop losses in Raya Azebo during the 2017 drought was Kiremt Rainfall (Table 3). The coefficient of determination $\left(r^{2}\right)$ obtained shows that $37.1 \%$ of the variations in the yield loss ratio obtained in the study area in 2017 is attributed to the kiremt rainfall values (Table 3).

\section{Endamehoni (highland)}

Key results found for this area indicate that YpHa and SCY are moderately positively correlated with Annual and June Dev-NDVI (Supplementary Table S6). The SCY however shows a strong positive relationship with kiremt Dev-NDVI, August and September Dev-NDVI. The YLR had a strong negative significant relationship with kiremt Dev-NDVI, September SPI-3; July, September and October SPI-12. The variable also had a moderate negative correlation with annual and June Dev-NDVI; July, September and October SPI-1; October SPI-3 values.

The most relevant predictors of SCY in Endamehoni are September Dev-NDVI and the 2017 Kiremt Dev-NDVI in a two-step computation (Supplementary Table S8). The coefficient of determination $\left(r^{2}\right)$ show that only the September Dev-NDVI as a predictor of SCY explain $29.5 \%$ of the variation, while the addition of the kiremt season Dev-NDVI for the year explains $46.9 \%$ variation in standardized crop yield in the area for the year under review (Table 3). Similarly, the September Dev-NDVI is the sole predictor of YpHa in the area with $45.2 \%$ of variations explained in the one-step regression implemented (Table 3). September SPI-3 is the only, most relevant and significant predictor of crop losses in this location for the year 2017. The coefficient of determination $\left(r^{2}\right)$ shows that September SPI-3 explains $45.4 \%$ of the variation in yield loss ratio in the area (Table 3). A nearly-significant predictor is the June Dev-NDVI with $(\mathrm{p}=.052)$. 


\section{Entire study area}

The results depict a moderate positive significant relationship between annual rainfall, kiremt season rainfall, annual NDVI and YpHa (Supplementary Table S4). Similarly, a moderate positive significant relationship is with Annual NDVI and SCY. Also, the July, September and October SPI-1; September and October SPI-3; together with June, July and October SPI-12 all show a moderate positive relationship with YpHa and SCY. In correlating the crop loss with the various factors, only the annual Rainfall and kiremt season rainfall shows a positive significant relationship with YLR, while June SPI-3 values show a moderate positive significant relationship.

Annual NDVI and July SPI-12 are the key predictors of SCY from the two-step multiple regression analysis implemented (Supplementary Table S8). Annual NDVI alone explains 19.6\% of the variation in the standardized crop yield while the combination of both predictors - annual NDVI and the July SPI-12 values for the year explain $33.1 \%$ of the variation in SCY (Table 3). However, for the YpHa, July SPI-12 as the only and most relevant and significant predictor with the coefficient of determination $\left(r^{2}\right)$ obtained shows that $24.4 \%$ of the variations in the yield per hectare obtained in the study area is attributed to the July SPI-12 values (Table 3).

The most significant predictors of yield loss in the study area are kiremt rainfall and September SPI-3. The coefficient of determination $\left(r^{2}\right)$ show that kiremt rainfall alone explains $19 \%$ of the variation in yield loss ratio; while the combination of kiremt rainfall and September SPI-3 explain 33\% variations in yield loss within the entire study area (Table 3).

Table 3: Predictors of YpHa, SCY and YLR in the 2017 drought year in the study area 


\begin{tabular}{|c|c|c|c|c|c|c|}
\hline Location & Variable & $\begin{array}{c}\text { Highest } \\
\text { reqression step }\end{array}$ & Predictors & $\mathbf{R}$ & $\mathbf{R}^{2}$ & Sig. \\
\hline \multirow[t]{11}{*}{ Raya Azebo } & \multirow[t]{5}{*}{ YpHa } & \multirow[t]{5}{*}{7} & \multirow[t]{5}{*}{$\begin{array}{l}\text { sep17_DNDVI, jun17_DNDVI, aug17_DNDVI, } \\
\text { june17_SPI12, DNY2017 }\end{array}$} & \multirow[t]{5}{*}{.983} & .966 & $.027 *$ \\
\hline & & & & & & $.000 * * *$ \\
\hline & & & & & & $.004^{* *}$ \\
\hline & & & & & & $.000 * * *$ \\
\hline & & & & & & $.000 * * *$ \\
\hline & \multirow[t]{5}{*}{ SCY } & \multirow[t]{5}{*}{7} & \multirow{5}{*}{$\begin{array}{l}\text { ND17, jun17_DNDVI, aug17_DNDVI, } \\
\text { jul17_DNDVI, oct17_DNDVI }\end{array}$} & \multirow[t]{5}{*}{.980} & .960 & $.000^{* * *}$ \\
\hline & & & & & & $.000 * * *$ \\
\hline & & & & & & $.000 * * *$ \\
\hline & & & & & & $.009 * *$ \\
\hline & & & & & & $.029 *$ \\
\hline & YLR & 1 & KRFE2017, & .609 & .371 & $.012 *$ \\
\hline \multirow[t]{4}{*}{ Endamehoni } & YpHa & 1 & Sep17_DNDVI & .672 & .452 & $.002^{* *}$ \\
\hline & SCY & 2 & sep17_DNDVI, KSDN17 & .685 & .469 & $.007^{* *}$ \\
\hline & & & & & & $.043^{*}$ \\
\hline & YLR & 1 & sep17_SPI3 & .674 & .454 & $.002^{* *}$ \\
\hline \multirow[t]{5}{*}{ Entire area } & YpHa & 1 & Jul17_SPI12 & .494 & .244 & $.003^{* *}$ \\
\hline & SCY & 2 & ND17, Jul17_SPI12 & .575 & .331 & $.015^{*}$ \\
\hline & & \multirow{3}{*}{2} & & & & $.018^{*}$ \\
\hline & \multirow[t]{2}{*}{ YLR } & & \multirow[t]{2}{*}{ KRFE2017, sep17_SPI3 } & \multirow[t]{2}{*}{.575} & .330 & $.002^{* *}$ \\
\hline & & & & & & $.016 *$ \\
\hline
\end{tabular}

*** Regression Predictor is significant at the above 0.001 level

**. Regression Predictor is significant at the 0.01 level

*. Regression Predictor is significant at the 0.05 level

\section{Discussion}

The year 2015 is adjudged as the most recent drought year of high magnitude and one of the worst events over the past 30 years covering a large area and exacerbating food insecurity in Ethiopia (Bayissa et al., 2018; WFP, 2016). These literature reports are supported by an evidence of low crop yield in a larger part of the study area (Figure 2). In addition, the year 2017 is recorded as the most recent drought year in some parts of Tigray/Ethiopia with Gross Domestic Product (GDP) losses due to climate variability estimated to be around $1 \%$ to $4 \%$ excluding human losses (FDRE, 2017). These events were expected to have impacted on crop yield and yield losses in the study area.

From this study, drought has again been proven to be location-specific, and not a broad spatio-temporal phenomenon at any given time. In an earlier study, Viste et al. (2013) describe most historic droughts as being more of 'local or regional character' with dissimilar effects at different places and seasons. Each drought year reviewed (2015 and 2017) stands out uniquely in its nature and characteristics. The only common denominator is precipitation-deficit, which in itself may be of different magnitude per location. Overall, the seasonal rainfall benchmark of $500 \mathrm{~mm}$ as stipulated by Haile et al. (2019) for a rough drought indicator in a season helps to present an outlook of the drought. In 2015 the entire study area fell below the 500mm mark, while in 2017, only one tabia/kabele (village) did. Hence the 2015 drought was more widespread than that of 2017, with majority of farmers in the lowland reporting entire crop losses. The predictors of yield and yield losses indicate that droughts coinciding with planting and maturing stages of crops are critical and inimical to crop production and agricultural sustainability and food security. 
In both years, and for the entire study area, both annual and the kiremt seasonal rainfall were related to the crop yield reported by farmers in these years. Crop yield is largely a function of adequate soil moisture at all stages of crops. Hence, the shortage of rainfall (occurrence of drought) brought about reduced crop yield in the area. These assertions are corroborated by the findings of Gidey, Dikinya, Sebego, Segosebe, and Zenebe (2018), who report that agricultural drought responds positively to seasonal rainfall. Also, part of the findings of Molla and Fitsume (2017) Legesse and Suryabhagavan (2014); and Legesse (2010) indicate that rainfall significantly determines the occurrence of drought, hence manifesting high influence on the growth and development of vegetation.

Different timescales of SPI, especially the 3- and 12-month scales were recurring predictors of crop yield in the area. In relating meteorological drought index for drought monitoring, several studies have found a significant relationship between SPI and crop yield (Elagib and Elhag, 2011; Li et al., 2014; Melese et al., 2018). Also, the vegetation anomaly (Dev-NDVI) is able to detect agricultural drought, and predict crop yield in the area. These rainfall and vegetation based indices used in this study considered vis-à-vis specific crop timelines are helpful to clarify the times drought were more critical. For example, the SPI-3 for July 2015 predicted sorghum yield for the lowland portion of the study area, because sorghum crops are at their early stages of growth at this time. In the mid and highland areas, the Dev-NDVI for October 2015 predicted yield and yield loss as the late maturity period for barley includes October. Hence, the satellites detected low vegetation vigor, indicating drought at the time. For the Dev-NDVI to detect agricultural drought in October, it also implies that preceding moisture deficit has occurred.

The reduced impact of drought on crop yield in 2017, especially in the lowland area is attributable to the increased rainfall received. Most of the tabias received rainfall higher than $500 \mathrm{~mm}$, which supports healthy agriculture. Additionally, the report of Madajewicz et al. (2017) contains Oxfam's contribution to the minimization of drought risks by the construction of canals covering 862 hectares of land to supplement rain-fed agriculture in the event of drought event, pointing to increased popularity of spate irrigation systems. This may likely have been utilised in these areas resulting in reversing the report of $100 \%$ crop losses witnessed in 2015, and obtaining above-normal crop yield in 2017, in spite of droughts. Steenbergen et al. (2011) describe the dual benefit of spate irrigation as being a means of both soil and water conservation. Hence, while water channeled from the highlands to the midlands and lowlands are stored for use as required, the alluvial deposit that accompanies the flood are rich in nutrients to improve crop yields and reduce costs of purchasing fertilizers (Steenbergen et al., 2011).

\section{Conclusion}

This study critically assessed the recent drought years in northern Ethiopia, with a focus on a small area containing high, mid and lowland agroecologies. Results obtained show droughts as having spatiotemporal variations and impacts, with its primary

and common reflection being reduced vegetation amount. This translates to crop failures, reduced income of smallholders, food shortages and food insecurity. SPI, NDVI and Dev-NDVI were found quite useful as indicators of drought, and considered able to be applied in the preparation of early warning for droughts when they fall below a certain established threshold for the area in each cropping season, especially at critical crop growth and maturity stages. Findings of this study can provide information for further discussions in improving drought monitoring at lower locational scales. Spate irrigation should be further popularized in the low-lying areas of Raya Azebo as a means to augmenting for deficiencies in the kiremt rainfall. This will provide adequate water supply to meet the crops' water requirements especially during the growing and maturity periods, during future drought years, thus improving chances of future food security even in the event of future droughts. There are more factors responsible for crop losses not captured in this study, hence providing an aspect for future further research.

\section{Limitations and further research}


The findings of this study would have been more generalizable if the number of farmers that constituted the sample size were more in the number. The exclusion of temperature as a variable in this study is an obvious limitation, which would have provided improved outcome for drought assessment, especially with the use of SPEI, instead of SPI. Future studies can address these deficiencies, in addition to more detailed analysis of specific crops' growth stages with climatic variables, and the impact of the use of spate irrigation systems, for more robust outcomes. Spate irrigation was not considered a priori as a factor that could affect the impacts of droughts in the area, hence further inquiry was not considered in this regard.

\section{Declarations}

\section{Data availability}

The datasets used for this study are available and can be provided by the corresponding author on request.

\section{Declaration of competing interests}

The authors hereby declare no competing interests.

\section{Funding}

No external funding was received for this study.

\section{Author's contributions}

All authors contributed, read and approved the final manuscript.

\section{Acknowledgments}

The lead author is grateful to staff at Institute of Climate and Society, Mekelle University, Ethiopia for creating an enabling environment of knowledge-acquisition during his MSc programme.

\section{References}

Bachmair, S., Tanguy, M., Hannaford, J., Stahl, K., 2018. How well do meteorological indicators represent agricultural and forest drought across Europe? Environ. Res. Lett. 13, 10. https://doi.org/10.1088/1748-9326/aaafda

Bayissa, Y., Maskey, S., Id, T.T., Andel, S.J. Van, Moges, S., Griensven, A. van, Solomatine, D., 2018. Comparison of the Performance of Six Drought Indices in Characterizing Historical Drought for the Upper Blue Nile Basin, Ethiopia. Geosciences 8 , 26. https://doi.org/10.3390/geosciences8030081

Bayissa, Y.A., 2018. Developing an Impact-Based Combined Drought Index for Monitoring Crop Yield Anomalies in the Upper Blue Nile Basin , Ethiopia. Delft University of Technology.

Bayissa, Y.A., Tadesse, T., Svoboda, M., Wardlow, B., Poulsen, C., Swigart, J., Van Andel, S.J., 2018. Developing a satellite-based combined drought indicator to monitor agricultural drought: a case study for Ethiopia. GIScience Remote Sens. 1-31.

https://doi.org/10.1080/15481603.2018.1552508

Blauhut, V., Stahl, K., Stagge, J.H., Tallaksen, L.M., Stefano, L. De, Vogt, J., 2016. Estimating drought risk across Europe from reported drought impacts, drought indices, and vulnerability factors. Hydrol. Earth Syst. Sci. 20, 2779-2800. https://doi.org/10.5194/hess-20-2779-2016

Clarke, D., 2017. Assessing the impacts of drought on UK wheat production. Cranfield University.

Cohen, J., Cohen, P., West, S.G., Aiken, L.S., 2003. Applied Multiple Regression/Correlation Analysis for the Behavioral Sciences, Third. ed. Lawrence Erlbaum Associates, Mahwah, NJ. 
Elagib, N.A., Elhag, M.M., 2011. Major climate indicators of ongoing drought in Sudan. J. Hydrol. 409, 612-625.

Elhag, K.M., Zhang, W., 2018. Monitoring and Assessment of Drought Focused on Its Impact on Sorghum Yield over Sudan by Using Meteorological Drought Indices for the Period 2001-2011. Remote Sens. 10, 1-21. https://doi.org/10.3390/rs10081231

Eze, E., Girma, A., Zenebe, A.A., Zenebe, G., 2020. Feasible crop insurance indexes for drought risk management in Northern Ethiopia. Int. J. Disaster Risk Reduct. 47, 1-11. https://doi.org/10.1016/j.ijdrr.2020.101544

FDRE, 2017. Multi-Sector Investment Plan for Climate Resilient Agriculture and Forest Development 2017-2030.

Funk, C.C., Peterson, P.J., Landsfeld, M.F., Pedreros, D.H., Verdin, J.P., Rowland, J.D., Romero, B.E., Husak, G.J., Michaelsen, J.C., Verdin, A.P., 2014. A Quasi-Global Precipitation Time Series for Drought Monitoring, Data Series 832.

Gebrechorkos, S.H., Hulsmann, S., Bernhofer, C., 2018. Evaluation of Multiple Climate Data Sources for Managing Environmental Resources in East Africa. Hydrol. Earth Syst. Sci. 22, 4547-64. https://doi.org/doi.org/10.5194/hess-22-4547-2018

Gebrehiwot, T., Veen, A. Van Der, Maathuis, A. Ben, 2016. Governing Agricultural Drought: Monitoring using the Vegetation Condition Index. Ethiop. J. Environ. Stud. Manag. 9, 354-371. https://doi.org/doi: http://dx.doi.org/10.4314/ejesm.v9i3.9

Gidey, E., Dikinya, O., Sebego, R., Segosebe, E., Zenebe, A., 2018. Analysis of the long-term agricultural drought onset, cessation, duration, frequency, severity and spatial extent using Vegetation Health Index (VHI) in Raya and its environs, Northern Ethiopia. Environ. Syst. Res. 7, 18. https://doi.org/10.1186/s40068-018-0115-z

Gray, C., Mueller, V., 2012. Drought and Population Mobility in Rural Ethiopia. World Dev. 40, 134-145. https://doi.org/10.1016/j.worlddev.2011.05.023

Gunst, L., Rego, F.M.C.C., Dias, S.M.A., Bifulco, C., Stagge, J.H., Rocha, M.S., Van Lanen, H.A.J., 2014. Links between meteorological drought indices and yields (1979-2009) of the main European crops (No. Technical Report No. 36), J of Ecology.

Haile, G.G., Tanga, Q., Sun, S., Huang, Z., Zhang, X., Liu, X., 2019. Droughts in East Africa: Causes, impacts and resilience. EarthScience Rev. 193, 146-161. https://doi.org/10.1016/j.earscirev.2019.04.015

Jones, J.R., Choudhury, A., Domingo, J., Spaulding, A., Ostaszewski, K., Amamoo, G., Melton, H., Danso-Manu, M., Bill, R., Mahd, M., Odilov, A., 2011. Establishing an index insurance triggers for crop loss in Northern Ghana (No. Research Paper No. 7).

Kidwell, K.B., 1990. Global Vegetation Index User's Guide. Washington, D.C.

Kogan, F.N., 1995. Application of vegetation index and brightness temperature for drought detection. Adv. Sp. Res. 15, 91-100. https://doi.org/10.1016/0273-1177(95)00079-T

Legesse, G., 2010. Agricultural Drought Assessment using Remote Sensing and GIS Techniques. Addis Ababa University, Ethiopia.

Legesse, G., Suryabhagavan, K. V, 2014. Remote sensing and GIS based agricultural drought assessment in East Shewa Zone, Ethiopia. Trop. Ecol. 55, 349-363.

Li, R., Tsunekawa, A., Tsubo, M., 2014. Index-based assessment of Agricultural Drought in a Semi-arid Region of Inner Mongolia China. J. Arid Land 6, 3-15.

Madajewicz, M., Tsegay, A.H., Lee, R., 2017. Managing Risks in Smallholder Agriculture: The Impacts of R4 on Livelihoods in Tigray, Ethiopia from 2012 to 2016. Boston.

Marshall, M.T., Funk, C., Michaelsen, J., 2012. Agricultural Drought Monitoring in Kenya Using Evapotranspiration Derived from Remote Sensing and Reanalysis Data, in: Wardlow, B.D., Martha C. Anderson, Verdin, J.P. (Eds.), Remote Sensing of Drought: Innovative Monitoring Approaches. CRC Press/Taylor \& Francis, p. 30. 
Marteau, R., Sultan, B., Moron, V., Alhassane, A., Baron, C., Traoré, S.B., 2011. The onset of the rainy season and farmers' sowing strategy for pearl millet cultivation in Southwest Niger. Agric. For. Meteorol. 151, 1356-1369.

https://doi.org/10.1016/j.agrformet.2011.05.018

McKee, T.B., Doesken, N.J., Kieist, J., 1993. The relationship of drought frequency and duration of time scales, in: 8th Conference on Applied Climatology. American Meteorological Society, Anaheim, California, pp. 179-184.

Melese, A., Suryabhagavan, K. V., Balakrishnan, M., 2018. Multimodel and Vegetation Indices for Drought Vulnerability Assessment: A Case Study of Afar Region in Ethiopia. Remote Sens. L. 2, 1-14. https://doi.org/10.21523/gcj1.18020101

Mera, G.A., 2018. Drought and its impacts in Ethiopia. Weather Clim. Extrem. 22, 24-35.

https://doi.org/10.1016/j.wace.2018.10.002

Molla, M.A., Fitsume, Y.D., 2017. Seasonal rainfall and crop productivity in South West Ethiopia: Preliminary analysis for recent climate. Int. J. Water Resour. Environ. Eng. 9, 211-217. https://doi.org/10.5897/ijwree2017.0730

Mugalavai, E.M., Kipkorir, E.C., Raes, D., Rao, M.S., 2008. Analysis of rainfall onset, cessation and length of growing season for western Kenya. Agric. For. Meteorol. 148, 1123-1135. https://doi.org/10.1016/j.agrformet.2008.02.013

Negash, E., Gebresamuel, G., Embaye, T., Nguvulu, A., Meaza, H., Gebrehiwot, M., Demisse, B., Gebreyohannes, T., Nyssen, J., Zenebe, A. 2020. Impact of headwater hydrological deficit on the downstream flood-based farming system in northern Ethiopia. Irrigation and Drainage, Early View Online.

Negash, E., Gebresamuel, G., Embaye, TAG., Zenebe, A. 2019. The effect of climate and land-cover changes on runoff response in Guguf spate systems, northern Ethiopia. Irrigation and Drainage 68:399-408.

Qu, C., Hao, X., Qu, J.J., 2019. Monitoring Extreme Agricultural Drought over the Horn of Africa (HOA) Using Remote Sensing Measurements. Remote Sens. 11, 902. https://doi.org/10.3390/rs11080902

Shukla, S., Funk, C., Peterson, P., Mcnally, A., Dinku, T., Barbosa, H., Paredes-Trejo, F., Pedreros, D., Husak, G., 2017. The Climate Hazards group InfraRed Precipitation with Stations (CHIRPS) dataset and its applications in drought risk management. Geophys. Res. Abstr. 19.

Shukla, S., Mcnally, A., Husak, G., Funk, C., 2014. A seasonal agricultural drought forecast system for food-insecure regions of East Africa. Hydrol. Earth Syst. Sci. 18, 3907-3921. https://doi.org/10.5194/hess-18-3907-2014

Sivakumar, M.V.K., 2011. Agricultural Drought Indices, in: Sivakumar, M.V.K., Motha, P.R., Wilhite, A.D., Wood, A.D. (Eds.), WMO/UNISDR Expert Group Meeting on Agricultural Drought Indices. Murcia, Spain, pp. 1-197.

Steenbergen, F. Van, Mehari, A., Alemehayu, T., Almirew, T., Geleta, Y., 2011. Status and Potential of Spate Irrigation in Ethiopia. Water Resour. Manag. https://doi.org/10.1007/s11269-011-9780-7

Suryabhagavan, K. V., 2017. GIS-based climate variability and drought characterization in Ethiopia over three decades. Weather Clim. Extrem. 15, 11-23. https://doi.org/10.1016/j.wace.2016.11.005

Thenkabail, P.S., Amage, M.S.D.N., Smakhtin, V.U., 2004. The Use of Remote Sensing Data for Drought Assessment and Monitoring in Southwest Asia (No. 85), Research Report. Colombo, Sri Lanka.

Viste, E., Korecha, D., Sorteberg, A., 2013. Recent drought and precipitation tendencies in Ethiopia. Theor. Appl. Climatol. 112, 535-551. https://doi.org/10.1007/s00704-012-0746-3

Warner, J.M., Mann, M.L., 2018. Agricultural impacts of the 2015/2016 drought in Ethiopia using high-resolution data fusion methodologies, in: Filho, W.L. (Ed.), Handbook OfClimate Change Resilience. Springer International Publishing AG, pp. 1-26. https://doi.org/10.1007/978-3-319-71025-9_79-1

Page $16 / 22$ 
WFP, 2016. Drought In Ethiopia: 10 Million People In Need [WWW Document].

Wilhite, D.A., 2000. Drought as a Natural Hazard: Concepts and Definitions, in: Wilhite, D.A. (Ed.), Drought: A Global Assessment. Routledge, London, pp. 3-18. https://doi.org/digitalcommons.unl.edu/droughtfacpub/69

WMO, GWP, 2016. Handbook of Drought Indicators and Indices (No. WMO-No.1173), Weather Climate Water.

WMO, W.M.O., 2012. Standardized Precipitation Index User Guide (No. WMO No. 1090). Geneva, Switzerland.

Wu, D., Qu, J.J., Hao, X., 2015. Agricultural drought monitoring using MODIS- based drought indices over the USA Corn Belt. Int. J. Remote Sens. 36, 5403-5425. https://doi.org/10.1080/01431161.2015.1093190

Yahaya, M., Timothy, D.A., 2015. Climate change and its effect on grain crops yields in the middle belt in Nigeria. African J. Environ. Sci. Technol. 9, 641-645. https://doi.org/10.5897/ajest2015.1896

Zhu, N., Xu, J., Li, W., Li, K., Zhou, C., 2018. A Comprehensive Approach to Assess the Hydrological Drought of Inland River Basin in Northwest China. Atmosphere (Basel). 9, 1-17. https://doi.org/10.3390/atmos9100370

\section{Appendix: Supplementary Tables}

Table S1: Spearman's $\left(r_{s}\right)$ correlation results of yield, drought and several climatic/vegetative indicators for year 2015 in the study area

\begin{tabular}{|c|c|c|c|c|c|c|c|c|c|c|}
\hline \multirow[t]{3}{*}{ Yield Variables } & \multicolumn{10}{|c|}{ FACTORS } \\
\hline & \multirow{2}{*}{ ANRF } & \multirow[t]{2}{*}{ KRFE } & \multirow[t]{2}{*}{ AND } & \multirow[t]{2}{*}{ ANDND } & \multirow[t]{2}{*}{ KRDND } & \multicolumn{5}{|c|}{ Monthly DND } \\
\hline & & & & & & Jun & Jul & Aug & Sep & Oct \\
\hline YpHa $\left(\underline{r}_{\underline{s}}\right)$. & $0.74^{* *}$ & $0.75^{* *}$ & $0.54^{* *}$ & $0.44^{* *}$ & 0.10 & -0.17 & -0.25 & -0.08 & 0.13 & 0.08 \\
\hline $\operatorname{SCY}\left(r_{s}\right)$ & $0.71^{* *}$ & $0.73^{* *}$ & $0.52^{* *}$ & $0.40^{*}$ & 0.08 & -0.15 & -0.32 & -0.17 & 0.09 & 0.08 \\
\hline $\operatorname{YLR}\left(r_{s}\right)$ & $-0.73 * *$ & $-0.71^{* *}$ & $-0.43^{*}$ & -0.31 & -0.08 & 0.24 & 0.33 & 0.27 & -0.10 & -0.10 \\
\hline
\end{tabular}

\begin{tabular}{|c|c|c|c|c|c|c|c|c|c|c|c|c|c|c|c|}
\hline \multirow{3}{*}{$\begin{array}{l}\text { Yield } \\
\text { Variables }\end{array}$} & \multicolumn{15}{|c|}{ FACTORS } \\
\hline & \multicolumn{5}{|c|}{ Monthly SPI-1 } & \multicolumn{5}{|c|}{ Monthly SPI-3 } & \multicolumn{5}{|c|}{ Monthly SPI-12 } \\
\hline & Jun & Jul & Aug & Sep & Oct & Jun & Jul & Aug & Sep & Oct & Jun & Jul & Aug & Sep & Oct \\
\hline$\underline{\mathrm{Y}} \mathrm{pHa}\left(\underline{r}_{\underline{s}}\right)$ & $-0.55^{* *}$ & -0.29 & $-0.49 * *$ & 0.18 & $-0.59 * *$ & -0.25 & 0.17 & -0.17 & 0.61 ** & -0.29 & $-.52 * *$ & $0.66^{* *}$ & 0.06 & $0.68^{* *}$ & $0.51^{* *}$ \\
\hline $\operatorname{SCY}\left(r_{s}\right)$ & $-0.51 * *$ & -0.29 & $-0.47 * *$ & 0.15 & $-0.56 * *$ & -0.23 & 0.12 & -0.17 & $0.58^{* *}$ & -0.27 & $-.43^{*}$ & $0.64 * *$ & 0.08 & $0.66^{* *}$ & $0.48^{* *}$ \\
\hline $\operatorname{YLR}\left(r_{s}\right)$ & $0.59^{* *}$ & $0.34 *$ & $0.51^{* *}$ & -0.12 & $0.62 * *$ & 0.37 & -0.09 & 0.21 & $-0.51 * *$ & $0.35 *$ & $0.49^{* *}$ & $-0.61 * *$ & 0.00 & $-0.59 * *$ & $-0.41 *$ \\
\hline
\end{tabular}

Table S2: Spearman's $\left(r_{s}\right)$ correlation results of yield, drought and several climatic/vegetative indicators for year 2015 in Raya-Azebo

\begin{tabular}{|c|c|c|c|c|c|c|c|c|c|c|}
\hline \multirow[t]{3}{*}{ Yield Variables } & \multicolumn{10}{|c|}{ FACTORS } \\
\hline & \multirow[t]{2}{*}{ ANRF } & \multirow[t]{2}{*}{ KRFE } & \multirow[t]{2}{*}{ AND } & \multirow[t]{2}{*}{ ANDND } & \multirow[t]{2}{*}{ KRDND } & \multicolumn{5}{|c|}{ Monthly DND } \\
\hline & & & & & & Jun & Jul & Aug & Sep & Oct \\
\hline YpHa $\left(r_{s}\right)$ & $0.52 *$ & $0.59^{*}$ & -0.01 & -0.42 & -0.39 & -0.22 & -0.15 & -0.00 & 0.06 & 0.09 \\
\hline $\operatorname{SCY}\left(r_{s}\right)$ & $0.52 *$ & 0.45 & -0.18 & -0.36 & -0.34 & -0.19 & -0.23 & -0.15 & 0.07 & 0.06 \\
\hline $\operatorname{YLR}\left(r_{s}\right)$ & $-0.52 *$ & $-0.57 *$ & 0.18 & $0.51 *$ & 0.47 & 0.34 & 0.01 & 0.12 & 0.00 & 0.09 \\
\hline
\end{tabular}

\begin{tabular}{|c|c|c|c|c|c|c|c|c|c|c|c|c|c|c|c|}
\hline \multirow[t]{3}{*}{ Yield Variables } & \multicolumn{15}{|c|}{ FACTORS } \\
\hline & \multicolumn{5}{|c|}{ Monthly SPI-1 } & \multicolumn{5}{|c|}{ Monthly SPI-3 } & \multicolumn{5}{|c|}{ Monthly SPI-12 } \\
\hline & Jun & Jul & Aug & Sep & Oct & Jun & Jul & Aug & Sep & Oct & Jun & Jul & Aug & Sep & Oct \\
\hline YpHa $\left(r_{s}\right)$ & $-0.52 *$ & -0.35 & -0.39 & -0.13 & $-.52 *$ & -0.43 & -0.13 & -0.13 & 0.05 & -0.43 & -0.37 & 0.41 & -0.08 & 0.33 & -0.02 \\
\hline $\operatorname{SCY}\left(r_{s}\right)$ & $-0.51 *$ & -0.39 & -0.47 & -0.29 & $-.51 *$ & -0.43 & -0.29 & -0.36 & -0.06 & -0.43 & 0.00 & 0.24 & -0.15 & 0.21 & -0.20 \\
\hline $\operatorname{YLR}\left(r_{s}\right)$ & $0.52 *$ & 0.43 & 0.27 & 0.219 & $0.52 *$ & 0.48 & 0.22 & 0.03 & 0.08 & 0.48 & 0.36 & -0.37 & 0.08 & -0.21 & 0.14 \\
\hline
\end{tabular}


Table S3: Spearman's $\left(r_{s}\right)$ correlation results of yield, drought and several climatic/vegetative indicators for year 2015 in Endamehoni

\begin{tabular}{|c|c|c|c|c|c|c|c|c|c|c|}
\hline \multirow[t]{3}{*}{ Yield Variables } & \multicolumn{10}{|c|}{ FACTORS } \\
\hline & \multirow[t]{2}{*}{ ANRF } & \multirow[t]{2}{*}{ KRFE } & \multirow[t]{2}{*}{ AND } & \multirow[t]{2}{*}{ ANDND } & \multirow[t]{2}{*}{ KRDND } & \multicolumn{5}{|c|}{ Monthly DND } \\
\hline & & & & & & Jun & Jul & Aug & Sep & Oct \\
\hline YpHa $\left(r_{s}\right)$ & 0.056 & -0.461 & -0.333 & -0.162 & $-.577 *$ & -0.490* & 0.358 & 0.361 & 0.224 & 0.04 \\
\hline $\operatorname{SCY}\left(r_{s}\right)$ & -0.088 & -0.439 & -0.201 & -0.272 & $-.567 *$ & -0.385 & 0.16 & 0.163 & 0.067 & 0.035 \\
\hline $\operatorname{YLR}\left(r_{s}\right)$ & -0.189 & 0.389 & 0.366 & 0.414 & $.483^{*}$ & 0.409 & 0.173 & 0.144 & -0.245 & -0.251 \\
\hline
\end{tabular}

\begin{tabular}{|c|c|c|c|c|c|c|c|c|c|c|c|c|c|c|c|}
\hline \multirow[t]{3}{*}{ Yield Variables } & \multicolumn{15}{|c|}{ FACTORS } \\
\hline & \multicolumn{5}{|c|}{ Monthly SPI-1 } & \multicolumn{5}{|c|}{ Monthly SPI-3 } & \multicolumn{5}{|c|}{ Monthly SPI-12 } \\
\hline & Jun & Jul & Aug & Sep & Oct & Jun & Jul & Aug & Sep & Oct & Jun & Jul & Aug & Sep & Oct \\
\hline YpHa $\left(r_{s}\right)$ & -0.13 & $-0.55 *$ & -0.44 & $-0.62 * *$ & -0.13 & -0.44 & $-.58 *$ & -0.44 & $-.52 *$ & -0.44 & -0.27 & $-0.51 *$ & -0.44 & $-0.52 *$ & $-0.59 *$ \\
\hline $\operatorname{SCY}\left(r_{s}\right)$ & 0.02 & -0.43 & -0.30 & $-0.52 *$ & 0.02 & -0.30 & $-.51 *$ & -0.30 & $-.53 *$ & -0.30 & -0.12 & $-0.49 *$ & -0.30 & $-0.53 *$ & $-0.52 *$ \\
\hline $\operatorname{YLR}\left(r_{s}\right)$ & 0.17 & 0.47 & $.49 *$ & $0.50 *$ & 0.17 & $0.49 *$ & $0.57 *$ & $0.49 *$ & $0.55^{*}$ & $0.49 *$ & 0.10 & 0.45 & $.049 *$ & 0.551 & $0.61^{* *}$ \\
\hline
\end{tabular}

Table S4: Spearman's $\left(r_{s}\right)$ correlation results of yield, drought and several climatic/vegetative indicators for year 2017 in the study area

\begin{tabular}{|c|c|c|c|c|c|c|c|c|c|c|}
\hline \multirow[t]{3}{*}{ Yield Variables } & \multicolumn{10}{|c|}{ FACTORS } \\
\hline & \multirow[t]{2}{*}{ ANRF } & \multirow[t]{2}{*}{ KRFE } & \multirow[t]{2}{*}{ AND } & \multirow[t]{2}{*}{ ANDND } & \multirow[t]{2}{*}{ KRDND } & \multicolumn{5}{|c|}{ Monthly DND } \\
\hline & & & & & & Jun & Jul & Aug & Sep & Oct \\
\hline YpHa $\left(r_{s}\right)$ & $0.37 *$ & $0.38 *$ & $0.39 *$ & 0.00 & 0.13 & -0.07 & -0.12 & -0.05 & -0.08 & -0.01 \\
\hline $\operatorname{SCY}\left(r_{s}\right)$ & 0.26 & 0.29 & $0.45^{* *}$ & 0.07 & 0.22 & -0.03 & -0.15 & -0.08 & -0.10 & -0.00 \\
\hline $\operatorname{YLR}\left(r_{s}\right)$ & $0.41 *$ & $0.35^{*}$ & -0.24 & $-0.40^{*}$ & $-0.50 * *$ & -0.14 & 0.19 & -0.15 & -0.08 & -0.05 \\
\hline
\end{tabular}

\begin{tabular}{|c|c|c|c|c|c|c|c|c|c|c|c|c|c|c|c|}
\hline \multirow[t]{3}{*}{ Yield Variables } & \multicolumn{15}{|c|}{ FACTORS } \\
\hline & \multicolumn{5}{|c|}{ Monthly SPI-1 } & \multicolumn{5}{|c|}{ Monthly SPI-3 } & \multicolumn{5}{|c|}{ Monthly SPI-12 } \\
\hline & Jun & Jul & Aug & Sep & Oct & Jun & Jul & Aug & Sep & Oct & Jun & Jul & Aug & Sep & Oct \\
\hline YpHa $\left(r_{s}\right)$ & -0.15 & $0.39 *$ & -0.11 & $0.44^{* *}$ & $0.41 *$ & -0.10 & 0.04 & -0.12 & $0.46^{* *}$ & $0.43^{*}$ & $-0.45^{* *}$ & $0.47 * *$ & -0.18 & 0.33 & $0.46^{* *}$ \\
\hline $\operatorname{SCY}\left(r_{s}\right)$ & -0.07 & $0.36 *$ & -0.05 & $0.41 *$ & $0.36 *$ & -0.03 & 0.07 & -0.07 & $0.37 *$ & $0.36 *$ & $-0.37 *$ & $0.38^{*}$ & -0.11 & 0.28 & $0.37 *$ \\
\hline $\operatorname{YLR}\left(r_{s}\right)$ & -0.21 & -0.1 & -0.14 & -0.17 & -0.00 & $-0.38 *$ & -0.24 & -0.07 & 0.25 & 0.25 & -0.11 & 0.31 & 0.05 & 0.13 & 0.30 \\
\hline
\end{tabular}

Table S5: Spearman's $\left(r_{s}\right)$ correlation results of yield, drought and several climatic/vegetative indicators for year 2017 in Raya Azebo

\begin{tabular}{|c|c|c|c|c|c|c|c|c|c|c|}
\hline \multirow[t]{3}{*}{ Yield Variables } & \multicolumn{10}{|c|}{ FACTORS } \\
\hline & \multirow[t]{2}{*}{ ANRF } & \multirow[t]{2}{*}{ KRFE } & \multirow[t]{2}{*}{ AND } & \multirow[t]{2}{*}{ ANDND } & \multirow[t]{2}{*}{ KRDND } & \multicolumn{5}{|c|}{ Monthly DND } \\
\hline & & & & & & Jun & Jul & Aug & Sep & Oct \\
\hline YpHa $\left(r_{s}\right)$ & -0.32 & -0.01 & $0.66 * *$ & 0.35 & $0.53 *$ & -0.30 & -0.49 & -0.43 & -0.43 & -0.11 \\
\hline $\operatorname{SCY}\left(r_{s}\right)$ & -0.32 & -0.01 & $0.67 * *$ & 0.35 & $0.53^{*}$ & -0.30 & -0.48 & -0.42 & -0.42 & -0.13 \\
\hline $\operatorname{YLR}\left(r_{s}\right)$ & 0.35 & 0.46 & -0.17 & 0.02 & -0.13 & $0.51 *$ & $0.61 *$ & 0.20 & 0.17 & 0.07 \\
\hline
\end{tabular}

\begin{tabular}{|c|c|c|c|c|c|c|c|c|c|c|c|c|c|c|c|}
\hline \multirow[t]{3}{*}{ Yield Variables } & \multicolumn{15}{|c|}{ FACTORS } \\
\hline & \multicolumn{5}{|c|}{ Monthly SPI-1 } & \multicolumn{5}{|c|}{ Monthly SPI-3 } & \multicolumn{5}{|c|}{ Monthly SPI-12 } \\
\hline & Jun & Jul & $\mathrm{Aug}$ & Sep & Oct & Jun & Jul & Aug & Sep & Oct & Jun & Jul & Aug & Sep & Oct \\
\hline YpHa $\left(r_{s}\right)$ & 0.37 & 0.32 & 0.21 & $0.59^{*}$ & 0.32 & $.508^{*}$ & 0.01 & 0.16 & 0.04 & 0.15 & -0.2 & 0.02 & 0.07 & 0.00 & 0.09 \\
\hline $\operatorname{SCY}\left(r_{s}\right)$ & 0.37 & 0.32 & 0.21 & $0.59 *$ & 0.32 & $.508 *$ & 0.01 & 0.16 & 0.04 & 0.15 & -0.2 & 0.02 & 0.07 & 0.00 & 0.09 \\
\hline $\operatorname{YLR}\left(r_{s}\right)$ & -0.06 & 0.00 & 0.18 & -0.23 & 0.002 & $-0.50 *$ & -0.32 & 0.228 & 0.327 & 0.203 & 0.18 & 0.461 & 0.327 & 0.38 & $.507 *$ \\
\hline
\end{tabular}

Table S6: Spearman's $\left(r_{s}\right)$ correlation results of yield, drought and several climatic/vegetative indicators for year 2017 in Endamehoni 


\begin{tabular}{|c|c|c|c|c|c|c|c|c|c|c|}
\hline \multirow[t]{3}{*}{ Yield Variables } & \multicolumn{10}{|c|}{ FACTORS } \\
\hline & \multirow[t]{2}{*}{ ANRF } & \multirow[t]{2}{*}{ KRFE } & \multirow[t]{2}{*}{ AND } & \multirow[t]{2}{*}{ ANDND } & \multirow[t]{2}{*}{ KRDND } & \multicolumn{5}{|c|}{ Monthly DND } \\
\hline & & & & & & Jun & Jul & Aug & Sep & Oct \\
\hline YpHa $\left(r_{s}\right)$ & 0.02 & -0.17 & 0.13 & 0.11 & 0.23 & 0.30 & 0.29 & $0.54^{*}$ & $0.58^{*}$ & 0.16 \\
\hline $\operatorname{SCY}\left(r_{s}\right)$ & -0.05 & -0.12 & 0.30 & 0.14 & 0.28 & 0.39 & 0.26 & 0.43 & 0.43 & 0.18 \\
\hline $\operatorname{YLR}\left(r_{s}\right)$ & -0.00 & -0.38 & -0.42 & -0.32 & $-0.59 *$ & $-0.55 *$ & -0.15 & -0.14 & 0.05 & 0.09 \\
\hline
\end{tabular}

\begin{tabular}{|c|c|c|c|c|c|c|c|c|c|c|c|c|c|c|c|}
\hline \multirow[t]{3}{*}{ Yield Variables } & \multicolumn{15}{|c|}{ FACTORS } \\
\hline & \multicolumn{5}{|c|}{ Monthly SPI-1 } & \multicolumn{5}{|c|}{ Monthly SPI-3 } & \multicolumn{5}{|c|}{ Monthly SPI-12 } \\
\hline & Jun & Jul & Aug & Sep & Oct & Jun & Jul & Aug & Sep & Oct & Jun & Jul & Aug & Sep & Oct \\
\hline YpHa $\left(r_{s}\right)$ & -0.16 & 0.10 & -0.13 & -0.04 & -0.06 & -0.12 & 0.19 & -0.13 & 0.02 & -0.10 & -0.40 & 0.07 & -0.18 & -0.7 & 0.04 \\
\hline $\operatorname{SCY}\left(r_{s}\right)$ & -0.09 & 0.12 & -0.02 & 0.02 & -0.00 & -0.06 & 0.15 & -0.02 & 0.07 & -0.01 & -0.28 & 0.10 & -0.08 & 0.8 & 0.08 \\
\hline $\operatorname{YLR}\left(r_{s}\right)$ & 0.07 & -0.44 & -0.19 & -0.42 & -0.45 & 0.02 & -0.00 & -0.19 & $-.60 * *$ & -0.45 & 0.041 & $-0.57 *$ & 0.09 & $-0.52 *$ & $-0.50 *$ \\
\hline
\end{tabular}

** Correlation is significant at the 0.01 level (2-tailed).

* Correlation is significant at the 0.05 level (2-tailed).

ANRE - Annual Rainfall

ANDND - Annual Dev-NDVI

SCY - Standardized Crop Yield

\author{
KRFE - Kiremt Season Rainfall \\ KRDND - Kiremt Dev-NDVI
}

YLR - Yield Loss Ratio
AND - Annual NDVI

YpHa - Yield (Qt) per Hectare

DND - Dev-NDVI

Table S7: Regression coefficients predicting SCY, YLR and YpHa for 2015

\begin{tabular}{|c|c|c|c|c|c|c|c|c|c|}
\hline \multirow[t]{2}{*}{ Location } & \multirow[t]{2}{*}{ Model } & \multicolumn{2}{|c|}{ Results (Coefficients) } & \multirow[t]{2}{*}{ Model } & \multicolumn{2}{|l|}{ Results (Coefficients) } & \multirow[t]{2}{*}{ Model } & \multicolumn{2}{|c|}{ Results (Coefficients) } \\
\hline & & Variable(s) & $\operatorname{SCY}(\beta)$ & & Variable (s) & YLR $(\beta)$ & & Variable (s) & YpHa $(\beta)$ \\
\hline \multirow[t]{4}{*}{ Entire area } & & (Constant) & -64.527 & 2 & (Constant) & 295.572 & 1 & (Constant) & -113.684 \\
\hline & 3 & KRFE2015 & .157 & & KRFE2015 & -.897 & & Annual_RFE & .183 \\
\hline & & jun15_DNDVI & -149.109 & & jun15_DNDVI & 468.785 & & & \\
\hline & & ND15 & 105.757 & & & & & & \\
\hline \multirow[t]{3}{*}{ Raya Azebo } & 2 & (Constant) & -133.234 & 0 & $\begin{array}{l}{ }^{* *} \text { No variables were entered } \\
\text { into the model }\end{array}$ & & 2 & (Constant) & -143.076 \\
\hline & & Annual_RFE & .124 & & & & & Annual_RFE & .134 \\
\hline & & July15_SPI3 & 80.608 & & & & & July15_SPI3 & 87.755 \\
\hline \multirow[t]{3}{*}{ Endamekhoni } & 1 & (Constant) & -1.088 & 2 & (Constant) & -233.671 & 2 & (Constant) & 1.458 \\
\hline & & oct15_SPI12 & -194.002 & & sep15_SPI12 & 325.562 & & oct15_SPI12 & -240.513 \\
\hline & & & & & oct15_DNDVI & -331.157 & & Aug15_DNDVI & 44.231 \\
\hline
\end{tabular}

Table S8: Regression coefficients predicting SCY, YLR and YpHa for 2017 


\begin{tabular}{|c|c|c|c|c|c|c|c|c|c|}
\hline \multirow[t]{2}{*}{ Location } & \multirow[t]{2}{*}{ Model } & \multicolumn{2}{|c|}{ Results (Coefficients) } & \multirow[t]{2}{*}{ Model } & \multicolumn{2}{|c|}{ Results (Coefficients) } & \multirow[t]{2}{*}{ Model } & \multicolumn{2}{|c|}{ Results (Coefficients) } \\
\hline & & Variable (s) & $\operatorname{SCY}(\beta)$ & & Variable (s) & YLR $(\beta)$ & & Variable (s) & ҮрНа $(\beta)$ \\
\hline \multirow[t]{3}{*}{ Entire area } & 2 & (Constant) & -58.444 & 2 & (Constant) & 185.039 & 1 & (Constant) & -8.754 \\
\hline & & ND1 7 & 156.706 & & KRFE2017 & 1.160 & & jul17_SPI12 & 61.540 \\
\hline & & jul17_SPI12 & 40.771 & & sep17_SPI3 & -1087.97 & & & \\
\hline \multirow[t]{6}{*}{ Raya Azebo } & 7 & (Constant) & -78.447 & 1 & (Constant) & -735.855 & 7 & (Constant) & -143.327 \\
\hline & & ND1 7 & 348.824 & & KRFE2017 & 1.375 & & sep17_DNDVI & -52.981 \\
\hline & & jun17_DNDVI & -314.265 & & & & & jun17_DNDVI & -292.163 \\
\hline & & aug17_DNDVI & -137.483 & & & & & aug17_DNDVI & -85.806 \\
\hline & & jul17_DNDVI & 87.872 & & & & & june17_SPI12 & -483.187 \\
\hline & & oct17_DNDVI & -51.776 & & & & & DNY2017 & 558.930 \\
\hline \multirow[t]{3}{*}{ Endamekhoni } & 2 & (Constant) & 11.250 & 1 & (Constant) & 737.378 & 1 & (Constant) & 19.650 \\
\hline & & sep17_DNDVI & 167.665 & & sep17_SPI3 & -904.570 & & sep17_DNDVI & 215.363 \\
\hline & & KSDN17 & 29.275 & & & & & & \\
\hline
\end{tabular}

\section{Figures}

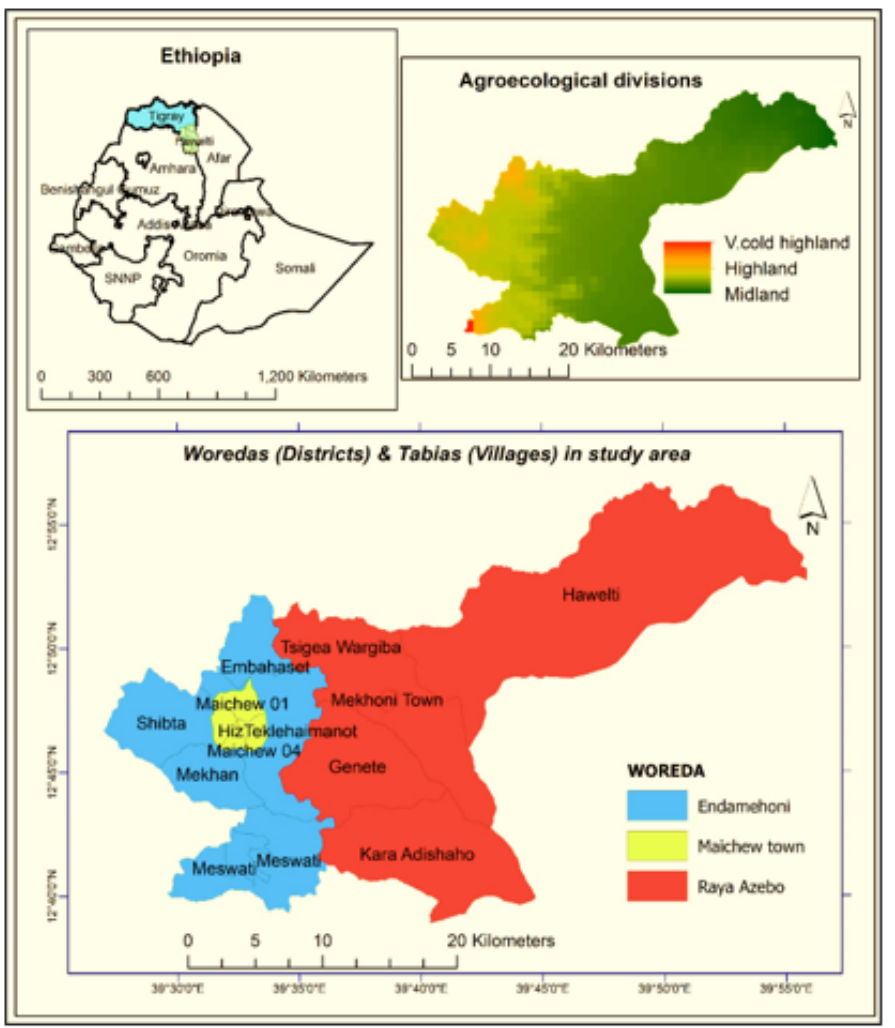

\section{Figure 1}

Study area map 

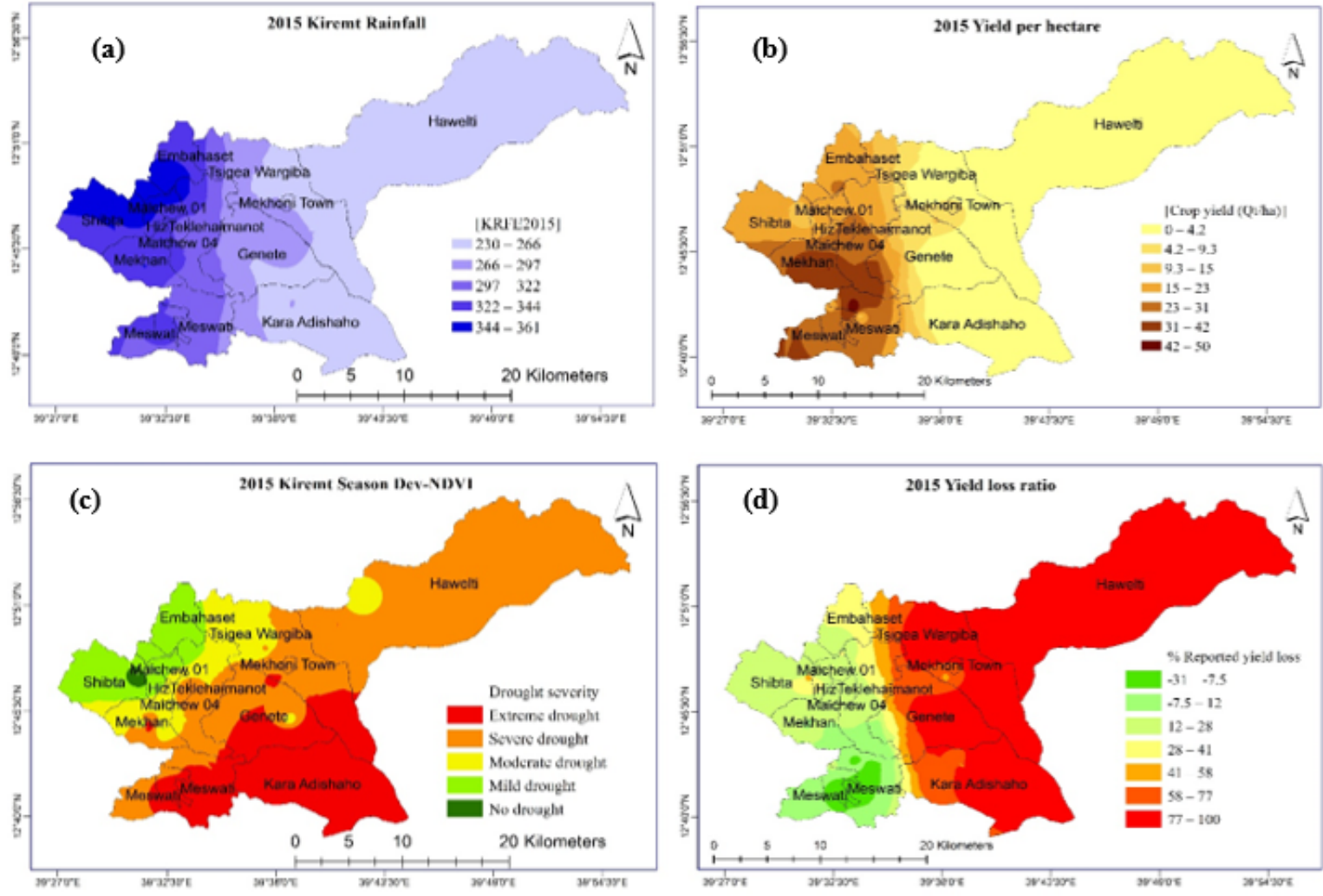

Figure 2

(a) Kiremt season rainfall (JJAS) (b) Farmers' reported yield (c) Kiremt season Dev-NDVI, and (d) Farmers' yield loss ratio for the 2015 farming season
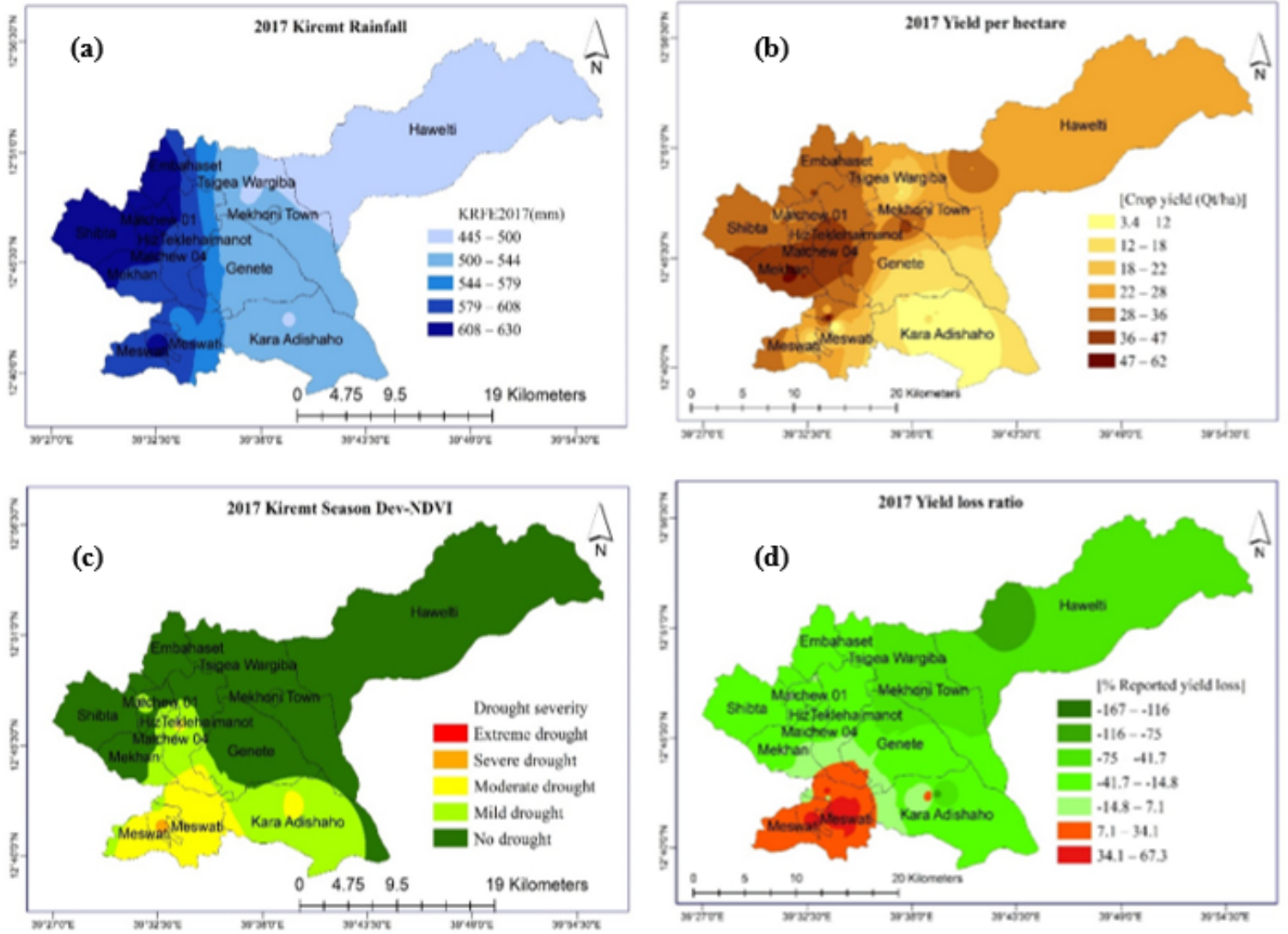

Figure 3 
(a) Kiremt season rainfall (JJAS) (b) Farmers' reported yield (c) Kiremt season Dev-NDVI, and (d) Farmers' yield loss ratio for the 2017 farming season 